\title{
Vaginal Glandular Neoplasm
}

National Cancer Institute

\section{Source}

National Cancer Institute. Vaginal Glandular Neoplasm. NCI Thesaurus. Code C40250.

A benign or malignant neoplasm that arises from the vagina and is characterized by the presence of neoplastic glandular epithelial cells. Representative examples include adenoma, endometrioid adenocarcinoma, and clear cell adenocarcinoma. 